\title{
Necrotic leg ulcers associated with krokodil injection in a 41-year-old man
}

\author{
Feras M. Ghazawi MD PhD, Jennifer Beecker MD
}

Cite as: CMAJ 2019 June 24;191:E712. doi: 10.1503/cmaj.190027

A

41-year-old man was admitted to hospital with painful necrotic leg ulcers (Figure 1). He exhibited narcoticseeking behaviour, such as requesting narcotics daily, refusing non-narcotic analgesia and hiding narcotics, but he denied using injection drugs. The patient's ulcers were irregular, with a peculiar black scale on the intact skin. Skin biopsy showed an extensive ulcer with neutrophilic inflammation, and heavy growth of Proteus vulgaris and Morganella morganii was seen on tissue culture. Our presumptive diagnosis was pyoderma gangrenosum with secondary infection. We prescribed prednisone, wound care and antibiotics, and our patient's lesions began to improve. At the same time, we managed his opioid withdrawal symptoms. About a month into our patient's stay in hospital, we learned from his roommate and family that he had been injecting a synthetic morphine derivative known as krokodil.

Krokodil is a highly addictive, inexpensive alternative to heroin that has been linked to thousands of deaths in Russia. ${ }^{1-4}$ In North America, usage is increasing, although it remains much less common than heroin. ${ }^{5}$ Krokodil has a short half-life, and therefore tends to be injected frequently. "Skin-popping," or injecting drugs into the skin, can induce extensive ulcerative necrosis. Krokodil is believed to cause more extensive skin necrosis than other injected drugs, for reasons that are unknown, with a characteristic green-black scaling likened to crocodile skin ("krokodil" in Russian). ${ }^{1-3}$ Our patient's late presentation, and his long stay in hospital before a definitive diagnosis, reflect the stigma of injection drug use.

\section{References}

1. Shelton M, Ramirez-Fort MK, Lee KC, et al. Krokodil: from Russia with love. JAMA Dermatol 2015;151:32.

2. Haskin A, Kim N, Aguh C. A new drug with a nasty bite: a case of krokodilinduced skin necrosis in an intravenous drug user. JAAD Case Rep 2016;2:174-6.

3. Thekkemuriyi DV, John SG, Pillai U. 'Krokodil' - a designer drug from across the Atlantic, with serious consequences. Am J Med 2014;127:e1-2.

4. Grund JP, Latypov A, Harris M. Breaking worse: the emergence of krokodil and excessive injuries among people who inject drugs in Eurasia. Int J Drug Policy 2013;24:265-74.

5. Babapoor-Farrokhran S, Caldararo MD, Rad SN, et al. New case of krokodil (desomorphine) use. Int J Case Rep Images 2018;9:100901Z01SB2018. doi: $10.5348 / 100901201 S B 2018 C R$.

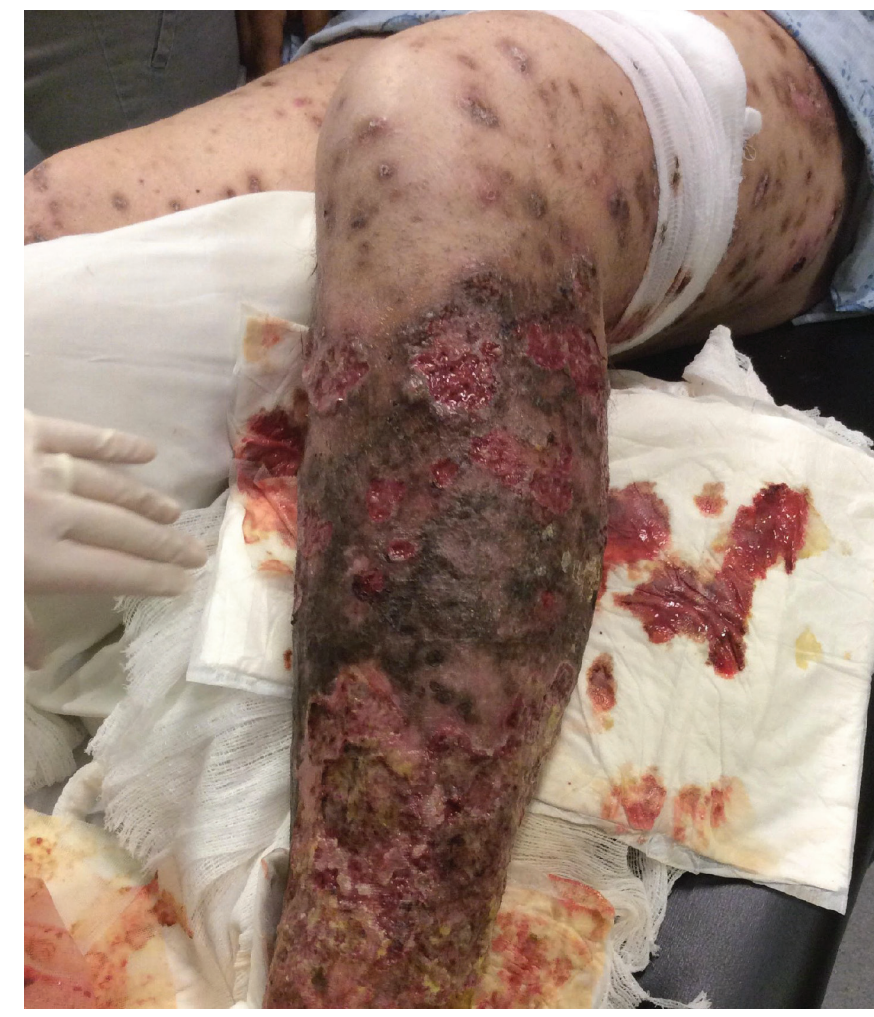

Figure 1: Left leg of a 41-year-old man with injection drug use, showing extensive necrotic ulcers at injection sites. Similar findings were seen on the right leg.

\section{Competing interests: None declared.}

This article has been peer reviewed.

The authors have obtained patient consent.

Affiliation: Division of Dermatology (Ghazawi, Beecker), University of Ottawa; Department of Medicine (Beecker), The Ottawa Hospital; Ottawa Hospital Research Institute (Beecker), Ottawa, Ont.

Correspondence to: Jennifer Beecker, jbeecker@ottawahospital.on.ca 